\title{
Biopsychosocial factors related to the length of hospital stay in older people
}

\author{
Laura Lorén Guerrero ${ }^{1}$
}

Ana Gascón Catalán ${ }^{2}$

This study aimed to know what variables influence increased length of hospital stay. A descriptive, cross-sectional study was conducted through an integrated geriatric assessment of 81 people over 65 years of age, admitted to a tertiary acute care hospital. Data were collected through the Pfeiffer Scale, Barthel Index, Goldberg Questionnaire, Family APGAR and Gijón Scale. The length of hospital stay increased in people over 80 years, people living alone or in a retirement home, patients with great physical dependence and those with a risk or problem of social exclusion. The most influential variable for longer hospitalization was cognitive impairment $(p<0.05)$, due to greater collaboration or desire to overcome the acute stage of the pathology that led to the hospital admission among patients without this condition.

Descriptors: Hospital Planning; Length of Stay; Aging; Activities of Daily Living; Cognition; Interpersonal Relations.

\footnotetext{
${ }^{1}$ RN, Unidad Docente Matronas, Zaragoza, Spain. E-mail: laurica10_03@hotmail.com.

2 Physician Ph.D. in Health Sciences, Profesor, Universidad de Zaragoza, Spain. E-mail: agascon@unizar.es.
} 


\title{
Variáveis biopsicossociais relacionadas à duração de hospitalização em idosos
}

Este estudo teve como objetivo conhecer quais as variáveis que influenciam o aumento do tempo de internação hospitalar. Trata-se de estudo descritivo e transversal, conduzido mediante ampla avaliação geriátrica de 81 pessoas com mais de 65 anos, internadas em hospital terciário de cuidados agudos. Os dados foram coletados através da Escala Pfeiffer, Índice de Barthel, Questionário de Goldberg, Apgar da Família e Escala de Gijón. Observou-se aumento no tempo de internação entre pessoas com mais de 80 anos, pessoas que vivem sozinhas ou em lar de idosos, pacientes que tinham grande dependência física, e entre aqueles com algum risco ou problema de exclusão social. A variável mais influente, para a maior duração da hospitalização, foi a deterioração cognitiva $(p<0,05)$, em comparação à maior colaboração do paciente sem essa condição ou ao seu desejo de superar a fase aguda da patologia que levou à internação hospitalar.

Descritores: Planejamento Hospitalar; Tempo de Internação; Envelhecimento; Atividades Cotidianas; Cognição; Relações Interpessoais.

\section{Variables biopsicosociales relacionadas con la duración de la estancia hospitalaria en personas mayores}

\begin{abstract}
Este estudio tuvo como objetivo conocer qué variables influyen en el aumento de la duración de la estancia hospitalaria. Se trata de un estudio descriptivo transversal en el que se realizó una Valoración Geriátrica Integral a 81 personas mayores de 65 años de edad que ingresaron en un hospital de agudos de tercer nivel. Para ello, los datos fueron recogidos por medio de la Escala de Pfeiffer, el Índice de Barthel, el Cuestionario de Goldberg, el APGAR familiar y la Escala de Gijón. Se observó un aumento de la duración de la estancia hospitalaria entre los mayores de 80 años, las personas que vivían solas o en una residencia geriátrica, los pacientes que presentaban gran dependencia física y también, entre quienes tenían un riesgo o problema de exclusión social. La variable que más influyó en la mayor duración de la hospitalización fue el deterioro cognitivo $(p<0,05)$, por la mayor colaboración del enfermo o por la propia voluntad de superar el estado agudo de la patología que motivó el ingreso.
\end{abstract}

Descriptores: Planificación Hospitalaria; Tiempo de Internación; Envejecimiento; Actividades Cotidianas; Cognición; Relaciones Interpersonales.

\section{Introduction}

Old age is a phase in the lifecycle when changes occur that decrease people's ability to adapt to new environmental conditions. It is a progressive and irreversible process that affects all living beings, but nevertheless with distinctive characteristics in each of these. Although aging as a definition is excessively biologistic, the concept "old age" is related to the time, age, context and culture one lives and develops in ${ }^{(1)}$.

As we can read in the European Council's White Paper on care delivery to people living in dependence situations, dependent people demand continuous, although not necessarily permanent, intervention, based on support and care ${ }^{(2)}$. Thus, care delivery to dependence fits into the social service context. A strong relation with the health context exists though, due to the fact that health problems that need healthcare can trigger or accelerate dependence processes in people of advanced ages. Moreover, occasionally, dependent people can be victims of acute processes in their health condition, which demand punctual healthcare. And, also, 
the existence of an adequate network to cover the social branch of dependence cases would discharge a large cost volume from the health system which, on the other hand, are disproportional to the care dependent people need.

The number of dependent people is already on the rise in all Western countries as a result of higher survival rates and accelerated population aging(3-5). A larger population of older and dependent people will impose higher economic demands on the working population and public budget. Therefore, dependent populations are one of the themes for improvement through adequate programs, which is one of the goals of the WHO's (World Health Organization) active aging programs, which include Integrated Geriatric Assessment, an instrument used to develop this study(6).

Today, Integrated Geriatric Assessment or Comprehensive Geriatric Assessment is considered a fundamental global diagnostic tool or method that supports geriatric clinical practice at all care levels, whose utility is universally accepted.

This Integrated Geriatric Assessment permits, at primary care level as well as it hospitals and social health centers, contact between patients and professionals, in which the therapeutic relation is established and plenty of information is obtained for care planning purposes. Similarly, when a needs assessment interview is held, an environment of trust is enhanced to start the relation between nursing and users receiving care. Consequently, when an individual plan is designed, adapted to the needs the patients expressed, whether concerning prevention, treatment or rehabilitation, a better care quality is achieved.

This research is proposed to get to know the health condition of elderly people hospitalized at an acute care hospital and to analyze what factors influence a longer hospitalization length, with a view to planning the necessary nursing care. Thus, the goal of this research is to get to know the cognitive status, physical dependence level, emotional status and social and family conditions of people over 65 years of age hospitalized at the Internal Medicine Unit. Also, the intent is to study and analyze which of these variables influence the increased length of hospital stay.

\section{Methods}

A descriptive and cross-sectional study was developed. Data were collected at the Internal Medicine hospitalization ward B of the Hospital Clínico
Universitario "Lozano Blesa" between February and April 2010. After obtaining approval from the hospital's Institutional Review Board, all patients over 65 years of age were selected who were hospitalized in that period, totaling 151.

Patients who died within the first 24 hours and patients isolated by the center's Preventive Medicine Service were excluded. Of course patients who did not want to cooperate and who did not sign the informed consent term were also excluded. In total, 70 persons were excluded and the final sample comprised 81 people.

Data collection took place on the indicated dates and was extended until all patients had been discharged, so as to collect information on the hospitalization length. The following socio-demographic data were collected: gender, age, marital status and social group. Data on the presence of degenerative diseases, psychopathological disorders and psychoactive drugs consumption were also included. After obtaining the necessary ethical consent from the Nursing Director at the center, data were collected from the computerized clinical history and the discharge report from the unit.

Interviews were held at the patients' rooms, closely considering non-verbal communication. To start the interviews, the patients received explanations about what the study involved and those willing to participate were asked to sign the informed consent form. Cooperation was only requested from close relatives of patients suffering from cognitive deterioration, so as to correctly fill out the physical dependence level.

The Pfeiffer Scale ${ }^{(7-10)}$ was used to assess the cognitive status and Barthel's Index ${ }^{(7-9,11)}$ for physical independence. In addition, tools were adopted that are useful for elderly people and assessed the emotional status, Goldberg's Questionnaire(7-9,12-13),

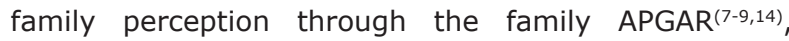
besides Gijón's Scale for the elderly's social-family assessment ${ }^{(7-9,15)}$. The Goldberg Questionnaire was preferred over others as it collects subjective data from the patients and assesses depression separately, which can provoke dependence and old age, and anxiety, which can be due to the hospitalization. All selected instruments were validated in Spain and are widely acknowledged among professionals.

The first instrument to complete was the Pfeiffer Scale as, depending on its result, the family's opinion on physical dependence would be taken into account and the other tools could not be used. That is, one cannot know the emotional, social or family status of 
people suffering from cognitive deterioration, studied through the selected indicator, as this research intends to achieve the subjective consideration of these three points.

\section{Analysis}

Data were analyzed in SPSS 15.0 statistical software and frequency distribution and central trend and dispersion measures were used. To establish the relation among the variables, inferential statistics was used. After studying the normality of variables through the Kolmogorov-Smirnov test, the researchers decided to analyze correlations among these variables through non-parametric statistics: Mann Whitney's $U$ test and Kruskal Wallis' test. Statistical significance was set as $\mathrm{p}<0.05$.

\section{Results}

\section{Socio-demographic variables}

Men corresponded to $53.7 \%$ and women $46.3 \%$ of participants and the mean age was 81.24 years $(\mathrm{SD}=7.338)$.

A majority had a partner $(50.6 \%)$, with only one case of divorce and one single participant. Widowed people corresponded to $46.8 \%$. In $47.4 \%$ of cases, the participants lived with their partner, $26.3 \%$ with daughters or sons, $15.8 \%$ at a retirement home and only $9.2 \%$ alone.

\section{Degenerative diseases and psychopathological disorders}

Degenerative diseases or psychopathological disorders are present in about $50 \%$ of sample patients. Moreover, nine participants suffer from more than one of this kind of pathologies. The collected alterations include 22 cases of Cerebrovascular Accident, also including lacunar infarctions and transitory ischemic accidents. Ten patients suffered from Alzheimer's Disease and two from Parkinson's. On the other hand, there were eight cases of Depressive Syndrome and, finally, five patients with cognitive deterioration, without a concrete pathology.

\section{Use of psychotropics}

Psychotropic consumption was found in $55.6 \%$ of the sample. In this group, 53.3\% takes anxiolytics, $4.4 \%$ antidepressants, and $31.1 \%$ a combination of both.

\section{Intellectual function assessment}

The median result on the Pfeiffer Test is three wrong answers. Extreme sample data correspond to $52.4 \%$ of the total. About $28 \%$ mistakenly answered all questions, while $24.4 \%$ did not commit any mistake. Among people with normal intellectual functioning, i.e. 0,1 and 2 wrong answers, $21.21 \%$ presents a degenerative disease or a psychopathological disorder. On the opposite, people with severe cognitive deterioration according to the scale, present some type of these diseases in $79.2 \%$ of cases. The most prevalent conditions are dementias (54.55\%), 40.74\% of which are Alzheimer's.

\section{Functional independence assessment}

The median score on the Barthel Index was 67.50. Totally dependent people correspond to $35.36 \%$ of the sample, $86.20 \%$ of whom have some degenerative disease or psychopathological disorder. On the opposite, among the $14.63 \%$ of independent patients, none of them suffers from any of these pathologies.

\section{Family and social assessment and emotional status}

The family, social and emotional assessment focused on 34 patients with adequate cognitive functioning according to the Pfeiffer Test. Eight were women and 26 men, 24 were younger and ten older than 80 years.

The mean score on the family APGAR is 9.15 $(S D=1.617)$, corresponding to $97.1 \%$ of the patients whose family functioning is interpreted as normal. Only one widowed woman younger than 80 and living along presents a severe family dysfunction.

The mean score on the Gijón scale is 9.44 $(S D=2.163)$. Considering that assessments in this scale use two groups: between 5 and 9 points for good or acceptable social situations and between 10 and 14 for social risk; the obtained mean score is on the borderline between both groups.

The mean score on the Anxiety Subscale is 2.06 $(S D=2.486)$. Scores of less than four are interpreted as absence of anxiety disorder, corresponding to $73.5 \%$ of the study sample. On the Depression Subscale, the mean score is $3.12(\mathrm{SD}=2.422)$, with scores higher than two representing the possibility of depressive disorder, found in $67.6 \%$ of cases. Finally, the mean score on the global scale corresponds to 5.29 ( $S D=4.145)$, 
interpreted as absence of emotional disorder, in 52.9\% of the sample.

\section{Results related to the length of hospitalization}

About $11.5 \%$ of hospitalized people who participated in the interviews, i.e. nine people, died during hospitalization. An in-depth analysis of these cases reveals that the mean age is 88.22 years $(S D=5.26)$, with four women and five men. Finally, six of these people suffered from some degenerative disease or psychopathological disorder. Moreover, none of the deceased showed adequate intellectual functioning and all of them were totally or severely dependent. Due to these deaths, these patients will not be taken into account to analyze the length of hospital stay. The mean hospitalization length is 14.56 days $(S D=10.344)$, without any significant relation with the patients' gender, age, presence of degenerative diseases or psychopathological disorders, nor with marital status or where these people lived.

A statistically significant association was found between the length of hospitalization and the Pfeiffer Test results, that is, patients with severe intellectual deficit show longer hospital stays, on the average nine days longer than patients with a normal cognitive level (Figure 1).

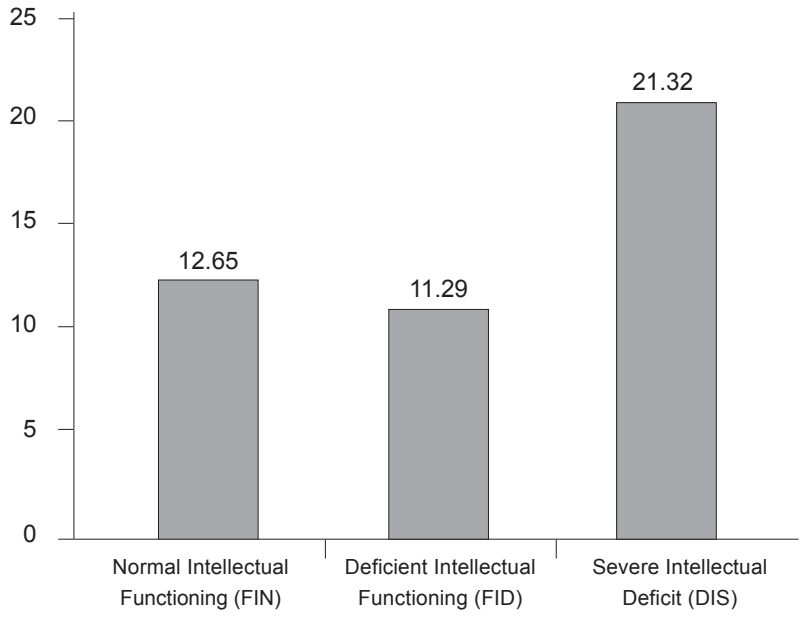

Figure 1 - Length of hospitalization according to patient's cognitive level in mean number of days

No significant relation was found between the other study variables when comparing them with the length of hospitalization (Tables 1 and 2). Although no statistically significant relation was found, data analysis reveals that the mean length of hospitalization is longer among women, people over 80 and living alone or in retirement homes. The same is true for dependence and the presence of social problems. The higher dependence and social risk, the longer the patient remains hospitalized.

Table 1- Bivariate statistical analysis between different variables and length of hospitalization

\begin{tabular}{|c|c|c|c|c|c|}
\hline \multicolumn{2}{|c|}{ Variables } & \multicolumn{4}{|c|}{ Length of hospitalization } \\
\hline & & \multirow{2}{*}{$\begin{array}{c}\mathbf{N} \\
37\end{array}$} & \multirow{2}{*}{$\frac{x}{15.03}$} & \multirow{2}{*}{$\begin{array}{c}\text { SD } \\
10.35\end{array}$} & \multirow{2}{*}{$\begin{array}{c}\mathbf{P} \\
0.943\end{array}$} \\
\hline Gender & Woman & & & & \\
\hline & Man & 44 & 14.16 & 10.45 & \\
\hline \multirow[t]{2}{*}{ Age } & $<80$ years & 33 & 12.76 & 4.64 & 0.977 \\
\hline & $>80$ years & 48 & 15.76 & 12.79 & \\
\hline \multirow[t]{2}{*}{ Neurological or emotional disease } & Yes & 41 & 14.22 & 9.42 & 0.666 \\
\hline & No & 40 & 14.9 & 11.33 & \\
\hline \multirow[t]{2}{*}{ Marital status } & Married & 39 & 14.26 & 7.59 & 0.834 \\
\hline & Widowed or Single or Divorced & 38 & 14.95 & 12.58 & \\
\hline \multirow[t]{3}{*}{ Home } & Husband/wife & 36 & 14.03 & 7.3 & 0.998 \\
\hline & Children or Brothers/Sisters & 21 & 13 & 6.25 & \\
\hline & Retirement home or Alone & 19 & 17.79 & 16.84 & \\
\hline
\end{tabular}

$\mathrm{N}=$ number of people; $\mathrm{X}=$ Mean; $\mathrm{SD}=$ Standard Deviation

Table 2 - Bivariate statistical analysis between different scales and length of hospitalization

\begin{tabular}{|c|c|c|c|c|c|}
\hline & \multirow{2}{*}{ Variables } & \multicolumn{4}{|c|}{ Length of hospitalization } \\
\hline & & $\mathbf{N}$ & $x$ & SD & $\mathbf{P}$ \\
\hline \multirow[t]{3}{*}{ Pfeiffer's Test } & Normal Intellectual Functioning & 34 & 12.65 & 5.9 & \multirow{3}{*}{$<0.05$} \\
\hline & Deficient Intellectual Functioning & 25 & 11.2 & 4.74 & \\
\hline & Severe Cognitive Deficit & 22 & 21.32 & 16.13 & \\
\hline \multirow[t]{3}{*}{ Barthel Index } & Total or Severe D. & 32 & 17.91 & 14.44 & \multirow{3}{*}{0.424} \\
\hline & Moderate or Mild D. & 36 & 12.58 & 5.75 & \\
\hline & Independent & 13 & 11.77 & 5.29 & \\
\hline
\end{tabular}


Table 2 - (continuation)

\begin{tabular}{llcccc}
\hline & \multicolumn{1}{c}{ Variables } & \multicolumn{3}{c}{ Length of hospitalization } \\
\cline { 3 - 6 } & & $\mathbf{N}$ & $\mathbf{X}$ & $\mathrm{SD}$ & $\mathbf{P}$ \\
\hline \multirow{2}{*}{ Family APGAR } & Normal function & 33 & 12.67 & 5.99 & - \\
& Severe dysfunction & 1 & - & - & \\
& Gijón Scale & 16 & 11.44 & 4.91 & 0.224 \\
& Good situation & 18 & 13.72 & 6.61 & \\
& Social risk or problem & &
\end{tabular}

$\mathrm{N}=$ number of people; $\mathrm{X}=$ Mean; $\mathrm{SD}=$ Standard Deviation

\section{Discussion}

The initial goal of this study was to investigate what variables affected the length of hospitalization. Therefore, personal, family and social variables were collected and patients' cognitive status, functional dependence level, family and social support and emotional status were analyzed through the use of validated scales.

The mean age of patients in this study, 81.24 years, is higher than in other research published(16-17), which could be due to the fact that this sample came from a hospital context. The same was found in a study that compares the community and hospital contexts $^{(18)}$. Moreover, in community research, cognitive deterioration is more limited than in research using a hospitalized sample(19). Therefore, the place the sample was extracted from should constantly be taken into account so as not to reach mistaken conclusions.

On the other hand, it should be proven whether hospitalization represents a risk factor for greater cognitive deterioration and functional dependence, or whether this type of patients shows greater fragility and, therefore, is hospitalized more frequently.

An observation on commonly used emotional status and social and family risk assessment scales is due, as the impossibility of using subjective scales with patients with cognitive deterioration represents a limitation. Therefore, scales should commonly be adjusted or created to study the emotional status and the family and social concept, with a view to the assessment of patients with cognitive deterioration who cannot complete the Comprehensive Geriatric Assessment scales, which impedes the assessment of some aspects and the establishment of a complete care plan for these individuals.

The analysis of results reveals participants' perception of their own family (family APGAR), with $97.1 \%$ presenting normal family functioning. Similar results were found in other studies, in which $84.3 \%$ consider their own family functions adequately(20). In other studies, however, the results found are very different, with only $12 \%$ of normal family functioning(21), although it should be taken into account that that research involved patients with longer hospital stays of more than 20 days.

In the present research, the large majority of participants feel loved, based on which one may say that the traditional family is still important in the current society, mainly at these ages. The main complaints people in this study demonstrate is the lack of time spent with their relatives. In other studies, the importance of the family as the main caregiver is highlighted, in addition to group activities as a family to maintain the elderly's social role and strengthen family bonds(20,22).

The mean score on the Gijón scale ranges between a good or acceptable social situation and a social risk. These results differ from other studies, with $88 \%$ of moderate social risk $^{(21)}$. This higher percentage is possibly due to the fact that participants remain hospitalized longer, and social risk may be involved in the longer length of hospitalization.

A lower anxiety level was observed than in other studies, in which $52 \%$ was found ${ }^{(21)}$. This difference can be due to the fact that this research involved patients with long hospitalization lengths, which may provoke greater anxiety.

In the instrument used, the most frequent affirmative answers are related to the appearance of vegetative symptoms and health concerns. The scale itself may be hiding the results as, when talking about patients hospitalized at a tertiary care institution, vegetative symptoms may be due to the disease itself questions and concern with the mere fact of being hospitalized. On the other hand, high psychotropic consumption may be reducing sample patients' actual anxiety levels, which the abovementioned article assesses ${ }^{(21)}$.

Discrepancies were also observed in the assessment of depression levels. More than half of the interviewees seems to suffer from some kind of depressive disorder, against only $23 \%$ in the other study(15). It should be highlighted that one-third of the present sample is taking antidepressants, an aspect not taken into account 
in the cited study. One very important point that should be considered, though, to assess depression in elderly patients, is family dynamics and the environment they live in, which is modified in the hospital context, in line with other studies(23-24). In the present study, most patients answer that they feel slowed down and have little energy, which could be due to the symptoms themselves that motivated the hospitalization.

Based on comments about the Anxiety and Depression Subscales of the Goldberg Scale, it is concluded that another scale should be used that would better assess the emotional status of elderly people hospitalized in an acute care facility.

The analysis of results reveals that variables like age over 80, living along or in a retirement home, high dependence level and presence of social risk could be influencing a longer length of hospitalization. In a published study with similar characteristics, an association was found between physical dependence and length of hospital stay ${ }^{(25)}$. The analysis of the present research variables showed, for some of them, a trend towards longer hospitalization, but without statistical significance. Therefore, further research would be useful to clarify this possible association.

Finally, statistically significant differences were found between the cognitive status and the length of hospital stay, possibly due to the patient's great cooperation and the desire itself to overcome the acute phase of the disease that motivated the hospitalization.

\section{Conclusion}

Altered cognitive status increases the length of hospital stay for older people in acute care hospitals.

\section{References}

1. Tarrés Chamorro S. Vejez y sociedad multicultural. Gac Antropol. [periódico na Internet]. 2002; 18. [acesso 26 nov 2010]. Disponível em: http://www.ugr.es/ pwlac/ G18_05Sol_Tarres_Chamorro.html

2. Ministerio de Sanidad y Política Social (ES). Libro Blanco de la Dependencia. 2004. [acesso 26 nov 2010]. Disponível em:

http://www.imsersomayores.csic.es/documentacion/ libro-blanco-dependencia.html

3. United Nations Population Division. World Population Prospects: the 2002 revision. [acesso 10 nov 2010]. Disponível em: http://www.un.org/esa/population/
4. United Nations. Population Division of the Department of Economic and Social Affairs of the United Nations Secretariat, World Population Prospects: The 2008 Revision. [acesso 8 Oct 2010]. Disponível em: http:// esa.un.org/unpp

5. Ministerio de Sanidad y Política Social (ES). Gobierno de Aragón. Informe anual del Sistema Nacional de Salud 2007: Aragón. [acesso 10 Oct 2010]. Disponivel em: http://www.msps.es/organizacion/sns/planCalidadSNS/

6. Organización Mundial de la Salud. Departamento de Promoción de la Salud. Hombres, envejecimiento y salud. 2001. [acesso 26 nov 2010].

Disponivel em: http://www.imsersomayores.csic.es/ salud/psicologia/vejez/documentos.html

7. Gallud J, Guirao Goris JA. Escalas e instrumentos para la valoración en Atención Domiciliaria. Valencia: Generalitat Valenciana. Conselleria de Sanitat, 2004. [acesso 26 nov 2010]. Disponivel em: http://www.san. gva.es/publicaciones/documentos/V.3785-2004.pdf 8. Servicio Andaluz de Salud (ES). Consejería de Salud. [acesso 26 nov 2010]. Disponivel em: www. juntadeandalucia.es/servicioandaluzdesalud/principal/

9. Programa de atención a enfermos crónicos dependientes. Gobierno de Aragón: departamento de salud y consumo. 2006.

10. Martínez de la Iglesia J, Dueñas Herrero R, Onis Vilches MC, Aguado Taberné C, Albert Colomer C, Luque Luque R. Cross-cultural adaptation and validation of Pfeiffer's test (Short Portable Mental Status Questionnaire [SPMSQ]) to screen cognitive impairment in general population aged 65 or older. Med Clin. 2001;117(4):129-34.

11. Baztán JJ, Pérez del Molino J, Alarcón T, San Cristobal E, Izquierdo G, Manzarbeitia J. Indice de Barthel: Instrumento válido para la valoración funcional de pacientes con enfermedad cerebrovascular. Rev Esp Geriatr Gerontol 1993;28:32-40.

12. Montón C, Pérez-Echevarría MJ, Campos R, García Campayo J, Lobo A y GMPPZ (Grupo de Morbilidad Psíquica y Psicosomática de Zaragoza). Goldberg's anxiety and depression scales (E.A.D.G.): a useful interview guideline for detection of psychological distress. Aten Primaria. 1993;12:345-9.

13. Lobo A, Montón A, Campos R, García-Campayo J, Pérez, Echevarría MJ. Detección de morbilidad psíquica en la práctica médica: el nuevo instrumento E.A.D.G. Zaragoza: Ed Luzán; 1993. 
14. Bellón Saameño JA, Delgado Sánchez A, Luna de Castillo J de D, Lardelli Claret P. Validity and reliability of the Apgar-family questionnaire on family function. Aten Primaria 1996;18(6):289-96.

15. Cabrera González A, Menenéndez Caicoya A, Fernández Sánchez A, Acebal García V, García González JV, Díaz Palacios A, Salamea García D. Evaluation of the reliability and validity of a scale of social evaluation of the elderly. Aten Primaria. 1999;23(7):434-40.

16. Navarro Pardo E, Meléndez Moral JC, Tomás Miguel JM. Relationship between psychological and physical dimensions of life quality in elderly persons. Gerokomos. 2008;19(2):63-7.

17. Cuesta Antelo MI. Implementation of a socio-medical assessment unit (UVASS) located in a hospital for acute patients (Fundation Hospital Son Llatzer: FHSLL). Gerokomos. 2008;1(1):16-20.

18. Martínez-Martín P, Fernández Mayoralas G, FradesPayo B, Rojo-Pérez F, Petidier R, Rodríguez-Rodríguez V, et al. Validation of the Functional Independence Scale. Gac Sanit. 2009;23(1):49-54.

19. Hervas A, García de Jalón E. Cognitive state as a conditioner of frailty in the elderly. Perspective from a health centre. An Sist Sanit Navar. 2005;28(1):35-47.

20. Mercedes Zavala G, Daisy Vidal G, Manuel Castros S, Quiroga P, Gonzalo Klassen P. Social functioning of elderly. Cienc Enferm. 2006;12(2):53-62.

21. Gómez González R, Sánchez Carrasco G, Rodríguez Aguilar GA. Vulnerabilidad de los pacientes mayores de 64 años a través de una valoración multidimensional. Invest Cuid. 2004;2(3):16-23.

22. Rojas Ocaña MJ, Toronjo Gómez A, Rodríguez Ponce C, Rodríguez Rodríguez JB. Autonomy and health status perceived by elderly institutionalised people. Gerokomos. 2006;17(1):6-23.

23. García Lozano L, Mérida Quiñones F, Mestre Reoyo I, Gallego Parrilla MD, Duarte Romero AJ, Mesa Ramos RG, et al. La depresión del anciano y el papel de la dinámica familiar. Aten Primaria. 2000;25(4):62-9.

24. Bocchi SCM, Silva L, Juliani CMCM, Spiri WC. Nurses' behaviours and their impacts on elderly hospitalized patients. Rev. Latino-Am. Enfermagem. 2007;15(2):1-7. 25. Blanca Gutiérrez JJ, Caraballo Núñez MA, Luque Pérez M, Muñoz Segura R. The increase of patient independence in hospital. Enferm. Global. 2009; 16. [acesso 28 ago 2010]. Disponivel em: http://www. scielo.br/scielo.php?script $=$ sci_issuetoc $\&$ pid $=0104$ $116920070002 \& \operatorname{lng}=$ en\&nrm $=$ iso

Received: Jan. $13^{\text {th }} 2011$ Accepted: Oct. $11^{\text {th }} 2011$ 